\title{
Coronary Artery Bypass Graft for Left Main Coronary Artery Disease
}

\author{
Husain H. Jabbad, FRCSC \\ Department of Surgery, Division of Cardiothoracic Surgery \\ Faculty of Medicine, King Abdulaziz University, Jeddah, Saudi Arabia
}

\section{Correspondence \\ Dr. Husain H. Jabbad \\ P.O. Box 80215, Jeddah 21589, Saudi Arabia \\ e.M: hjabbad@kau.edu.sa.com \\ Submission: 10 Dec. 2014 \\ Accepted: 23 Feb. 2015}

\section{Citation}

Jabbad HH. Coronary artery bypass graft for left main coronary artery disease. JKAU Med Sc 2015; 22 (2): 25-29. DOI: 10.4197/Med. 22.2.4

\begin{abstract}
Because leftmain coronaryartery disease carriesa high risk ofmorbidity and mortality, this retrospective study will review the data and results of surgical management of left main coronary artery disease, in King Abdulaziz University Hospital. 448 patients underwent coronary bypass graft into two groups, left main group (50) patients and nonleft main group (398) patients. Preoperative data, risk factors and cardiac catheterization findings were compared in between the two groups in addition to perioperative morbidity and mortality. Patients in the left main group were younger in age with significantly lower ejection fraction and more risk factors (hypertension, dyslipidemia, and smoking). In our study the left main group patients had higher mortality than non-left main patients $[4$ patients $=8 \%, 6$ patients $=$ $1.8 \%]$; the most common cause of perioperative mortality in the left main group was low cardiac output state, and the most common complications were perioperative myocardial infarction and prolonged ventilation. The higher mortality and morbidity associated with surgery for left main coronary artery disease can be explained by the higher risk profile, the need of urgent surgery and critical preoperative status.
\end{abstract}

\section{Keywords}

Left main coronary artery disease; Coronary artery bypass grafts

\section{Introduction}

$S$ gnificant left main coronary artery (LMCA) disease, defined as greater than $50 \%$ narrowing, occurs in $5-7 \%$ of patients undergoing coronary angiography ${ }^{[1]}$. Patients treated medically for LMCA disease have a 3-year survival rate of less than $50 \%{ }^{[2]}$. Several studies have shown a significant benefitfollowing the treatment of left main (LM) stenosis with coronary bypass grafting (CABG) compared with medical treatment ${ }^{[3]}$. Coronary bypass grafting has been the gold standard therapy for LM disease for many years. However, advances in percutaneous intervention techniques and stent technology have allowed evaluation of the role of percutaneous coronary intervention ( $\mathrm{PCl}$ ) for protected LM disease. Surgery is preferred in patients with heavily calcified LM disease, reduced left ventricular function LV function, diabetic patients particularly with insulin-dependent diabetes, multi-vessel disease MVD suitable for CABG, and distal LM bifurcation lesion with reduced LV function or with occluded right coronary artery RCA or with additional complex lesions on the other coronary vessels ${ }^{[4]}$.

\section{Patients and Methods}

448 patients underwent coronary artery bypass grafting at King Abdulaziz University Hospital, Jeddah, 
Saudi Arabia, between January 2009 and July 2014 . Patients were divided into two groups: left main group included 50 patients; non-left main group included 398 patients. All patients were informed about the procedure, the possible complications, and signed the informed consent. Preoperative data, operative, and postoperative data were collected. Follow up after operation by clinical and echocardiography evaluation was done at outpatient bases. All data retrospectively reviewed through patient's files and phoenix information system, chi-square $\left(\chi^{2}\right)$ test and $t$-test used to calculate $p$ value, $p$ value considered significant if below 0.05 .

\section{Results}

The total number of patients was $448: 50$ patients had LMCAD (Group 1), 398 patients had no LMCAD (Group 2). The demographic data and preoperative risk factors of all patients in group 1 and group 2 were analyzed and compared between the two groups: mean age (56.4 years \pm 8.8 and 57.8 years $\pm 9.8, \mathrm{P}=0.34$ ); gender distribution (42 males $=84 \%$ and 322 males $=80.9 \%$, $\mathrm{P}=0.59$ ); percentage of patients with diabetes mellitus (37 patients $=74 \%$ and 254 patients $=63.8 \%, \mathrm{P}=0.15$ ); percentage of patients with hypertension (35 patients $=70 \%$ and 183 patients $=45.9 \%, \mathrm{P}=0.001)$; percentage of patients with dyslipidemia ( 25 patients $=50 \%$ and 103 patients $=25.8 \%, \mathrm{P}<0.001$ ); percentage of patients with renal impairment ( 4 patients $=8 \%$ and 40 patients $=10.1 \%, P=0.64)$; percentage of smoking among the patients (23 patients $=46 \%$ and 103 patients $=25.8 \%$, $\mathrm{P}=0.002)$; percentage of obesity ( $\mathrm{BMI}>30)$ among the patients $(6=12 \%$ and $55=13.8 \%, P=0.72)$; percentage of patients with history of cerebrovascular accidents (CVA) (4 patients $=8 \%$ and 16 patients $=4 \%, \mathrm{P}=0.19$ ) (Table 1).
The main preoperative clinical presentation of patients in group 1 and group 2 was as follows: unstable angina ( 9 patients $=18 \%$ and 17 patients = 34\%); non ST elevation myocardial infarction (15 patients $=30 \%$ and 28 patients $=56 \%$ ); ST elevated myocardial infarction ( 26 patients $=52 \%$ and 6 patients $=12 \%), \mathrm{P}<0.001$ for all (Table 2 )

The preoperative cardiac catheterization and ejection fraction results in the two groups were: single vessel disease (0 patients $=0 \%$ and 23 patients $=5.8 \%$ ); double vessel disease $(9$ patients $=18 \%$ and 41 patients $=10.3 \%$ ); 3 vessel disease ( 41 patients $=82 \%$ and 334 patients $=83.9 \%), \mathrm{P}=0.07$ for all cardiac catheterization data; ejection fraction $(49.9 \pm 8.4$ SD and $57.1 \pm 9.7$ SD, $\mathrm{P}<0.001$ ), (Table 3).

Comparing the main operative data between the 2 groups: the number of grafts performed $(3.27 \pm 0.76$ SD and $3.46 \pm 0.95$ SD P $=0.96)$; cardiopulmonary bypass (CPB) time (124.3 $\pm 49.73 \mathrm{~min}$. and $95 \pm 31.3 \mathrm{~min} ., \mathrm{P}=$ $0.001)$; aortic cross clamp (AXC) time $(67.7 \pm 26.4 \mathrm{~min}$. and $54.1 \pm 17.1 \mathrm{~min} ., \mathrm{P}<0.001)$, (Table 4).

In the postoperative period group 1 patients required a higher use of inotrops and a need for intra-aortic balloon pump (IABP) counter pulsation (7 patients $=14 \%$ vs. 2 patients $=0.5 \%, \mathrm{P}<0.001$ ), group 1 required prolonged mechanical ventilation time (12.3 $\mathrm{h} \pm 8.36$ vs. $7.2 \mathrm{~h} \pm 3.89, \mathrm{P}=0.001)$, longer intensive care unit stay $(95.7 \mathrm{~h} \pm 30.3$ vs. $45.6 \mathrm{~h} \pm 17.1, \mathrm{P}=0.01)$, higher chest tube drainage (1214 $\mathrm{ml} \pm 307$ vs. $962 \mathrm{ml} \pm 230, \mathrm{P}$ $=0.01$ ), and longer hospital stay (11.3 days \pm 4.3 vs. 8.6 days $\pm 3.2, P=0.01$ ), (Table 5 ).

Group 1 had higher perioperative mortality rates (4 patients $=8 \%$ vs. 7 patients $=1.8 \%, \mathrm{P}=0.003$ ) and higher complication rate: myocardial infarction ( 8 patients $=16 \%$ vs. 17 patients $=4.2 \%, P=0.001)$

Table 1. Patient characteristics and demographic data for both groups.

\begin{tabular}{|l|c|c|c|}
\hline & $\begin{array}{c}\text { Left Main } \\
\mathbf{n}=\mathbf{5 0}\end{array}$ & $\begin{array}{c}\text { Non Left Main } \\
\mathbf{n}=\mathbf{3 9 8}\end{array}$ & P value \\
\hline Age mean \pm SD & $56.4 \pm 8.8$ & $57.8 \pm 9.8$ & 0.34 \\
\hline Gender: & $42(84.00 \%)$ & $322(80.90 \%)$ & 0.59 \\
Male (\%) & $8(16.00 \%)$ & $76(19.10 \%)$ & 0.15 \\
$\quad$ Female (\%) & $37(74.00 \%)$ & $254(63.80 \%)$ & 0.001 \\
\hline Diabetes mellitus (\%) & $35(70.00 \%)$ & $183(45.90 \%)$ & 0.001 \\
\hline Hypertension (\%) & $25(50.00 \%)$ & $103(25.80 \%)$ & 0.72 \\
\hline Dyslipidemia (\%) & $6(12.00 \%)$ & $55(13.80 \%)$ & 0.002 \\
\hline Obesity (\%) & $23(46.00 \%)$ & $103(25.80 \%)$ & 0.64 \\
\hline Smoking (\%) & $4(8.00 \%)$ & $40(10.10 \%)$ & 0.19 \\
\hline Renal impairment (\%) & $4(8.00 \%)$ & $16(4.00 \%)$ & \\
\hline CVA (\%) & & \\
\hline
\end{tabular}

$\pm S D=$ Standard deviation: $C V A=$ Cerebrovascular accident 
Table 2. Pre-operative clinical presentation for both groups.

\begin{tabular}{|l|c|c|c|c|}
\hline & $\begin{array}{c}\text { Left Main } \\
\text { N (\%) }\end{array}$ & $\begin{array}{c}\text { Non Left Main } \\
\text { N (\%) }\end{array}$ & & P value \\
\hline Unstable Angina & $9(18.00 \%)$ & $17(34.00 \%)$ & $135(33.90 \%)$ & \\
\cline { 1 - 4 } Non ST Myocardial Infarction & $15(30.00 \%)$ & $28(56.00 \%)$ & $217(54.50 \%)$ & $<0.001$ \\
\hline ST Myocardial Infarction & $26(52.00 \%)$ & $6(12.00 \%)$ & $46(11.60 \%)$ & \\
\hline
\end{tabular}

Table 3. Angiographic and echocardiographic criteria.

\begin{tabular}{|c|c|c|c|}
\hline & $\begin{array}{l}\text { Left Main } \\
\qquad=50\end{array}$ & $\begin{array}{c}\text { Non Left Main } \\
\mathrm{N}=398\end{array}$ & $P$ value \\
\hline SVD n (\%) & $0(0.00 \%)$ & $23(5.80 \%)$ & \multirow{3}{*}{0.07} \\
\hline DVDn (\%) & $9(18.00 \%)$ & $41(10.30 \%)$ & \\
\hline TVD n (\%) & $41(82.00 \%)$ & $334(83.90 \%)$ & \\
\hline $\mathrm{EF} \%($ mean \pm SD) & $49.9 \pm 8.4$ & $57.1 \pm 9.7$ & $<0.001$ \\
\hline
\end{tabular}

Table 4. Operative data.

\begin{tabular}{|c|c|c|c|}
\hline & $\begin{array}{l}\text { Left Main } \\
\text { Mean } \pm \text { SD }\end{array}$ & $\begin{array}{c}\text { Non Left Main } \\
\text { Mean } \pm \text { SD }\end{array}$ & $P$ value \\
\hline Numbers of Graft & $3.27 \pm 0.76$ & $3.46 \pm 0.95$ & $P=0.96$ \\
\hline CPB time/min & $124.3 \pm 49.73$ & $95 \pm 31.3$ & $P=0.001$ \\
\hline AXC time/min & $67.7 \pm 26.4$ & $54.1 \pm 17.1$ & $P<0.001$ \\
\hline
\end{tabular}

Table 5. Post-operative data.

\begin{tabular}{|l|c|c|c|}
\hline & $\begin{array}{c}\text { Left Main } \\
\mathbf{N}=\mathbf{5 0}\end{array}$ & $\begin{array}{c}\text { Non Left Main } \\
\mathbf{N}=\mathbf{3 9 8}\end{array}$ & P value \\
\hline On IABP (\%) & $\mathbf{7 ( 1 4 . 0 0 \% )}$ & $2(0.50 \%)$ & $<0.001$ \\
\hline Ventil. time $\mathrm{h}(\mathrm{mean} \pm$ SD) & $12.3 \pm 8.36$ & $7.2 \pm 3.89$ & 0.001 \\
\hline ICU stays $\mathrm{h}$ (mean \pm SD) & $95.7 \pm 30.3$ & $45.6 \pm 17.1$ & 0.01 \\
\hline Drainage $\mathrm{ml}$ (mean \pm SD) & $1214 \pm 307$ & $962 \pm 230$ & 0.01 \\
\hline Hospital stay days (mean \pm SD) & $11.3 \pm 4.3$ & $8.6 \pm 3.2$ & 0.01 \\
\hline
\end{tabular}

IABP = Intra-aortic balloon pump; ICU = Intensive care unit

Table 6. Post-operative complications.

\begin{tabular}{|l|c|c|c|}
\hline & $\begin{array}{c}\text { Left Main =50 } \\
\mathbf{N}(\%)\end{array}$ & $\begin{array}{c}\text { Non Left Main =398 } \\
\mathbf{N}(\%)\end{array}$ & P value \\
\hline Mortality & $4(8.00 \%)$ & $7(1.80 \%)$ & 0.003 \\
\hline Myocardial infarction & $8(16.00 \%)$ & $17(4.20 \%)$ & $<0.001$ \\
\hline Prolonged ventilation & $7(16.00 \%)$ & $16(4.00 \%)$ & 0.002 \\
\hline Exploration for bleeding & $3(6.00 \%)$ & $8(2.00 \%)$ & 0.08 \\
\hline DSWI & $6(12.00 \%)$ & $9(2.20 \%)$ & $<0.001$ \\
\hline CVA & $3(6.00 \%)$ & $7(1.70 \%)$ & 0.06 \\
\hline Renal impairment & $7(14.00 \%)$ & $40(10.10 \%)$ & 0.39 \\
\hline
\end{tabular}

$\overline{D S W I}=$ Deep sternal wound infection; SWI = Superficial wound infection; CVA = Cerebrovascular accident

prolonged ventilation ( 7 patients $=16 \%$ vs. 16 patients $=4 \%, \mathrm{P}=0.002)$; re-exploration for bleeding (3 patients $=6 \%$ vs. 8 patients $=2 \%, \mathrm{P}=0.08)$; sternal wound infection (6 patients $=12 \%$ vs. 9 patients $=2.2 \%$, $\mathrm{P}$ $<0.001)$; postoperative cerebrovascular accident $(3$ patients $=6 \%$ vs. 7 patients $=1.7 \%, P=0.06)$; transient postoperative renal impairment (7 patients $=14 \%$ vs. 40 patients $=10.1 \%, \mathrm{P}=0.39$ ); no permanent renal failure requiring hemodialysis among all patients, (Table 6). 


\section{Discussion}

In our study, we found that patients in left main group were younger and had significantly more patients with hypertension, dyslipidemia, and smoking. We also observed large numbers of left main patients presented by ST elevated myocardial infarction. Similar results were reported by Anders et al. ${ }^{[5]}$ : younger age, higher diabetes, hypertension, and renal impairment in the left main group.

Most of the patients in left main group had triple vessel disease, with impairment of left ventricular function, other studies have demonstrated similar results ${ }^{[5,6]}$. We observed significantly longer CPB time and $A X C$ time in the left main group. The increase in postoperative need to use IABP was significant, with significantly longer ventilation time, ICU stays, and hospital stay.

Mortality rate of CABG in patients with left main disease varies according to different reports from $2.8 \%-6 \%$ which is significantly higher than mortality in patients with no left main stenosis $1.7 \%-2 \%\left[{ }^{[7]}\right.$. The great difference in mortality rate depends on many factors. In our study we observed $8 \%$ mortality in left main group versus $1.8 \%$ mortality in non-left main group; this higher mortality rate is explained by the fact that most of our patients had a higher risk profile and that most of their surgeries were done on an urgent and emergency basis. Low cardiac output state was the most common cause of deaths, the most common complications after urgent $C A B G$ in our study are perioperative myocardial infarction, prolonged ventilation, and superficial and/ or deep wound infection.

\section{Conclusion}

Coronary artery bypass graft in left main coronary artery disease is associated with significantly higher mortality and morbidity than non-left main patients. This is mainly because of the higher risk profile and critical preoperative clinical status. Urgent or emergency surgery, long CPB time, and low preoperative ejection fraction add to the risk of morbidity and mortality. Despite the higher surgical mortality rate $(8 \%)$ after surgery for left main, a favorable early clinical outcome is observed, and an acceptable mid and long term outcome can be expected if the patients survive. Highquality clinical evidence is still needed to evaluate the result of left main coronary artery disease, and to define the optimal perioperative and operative management of these patients; clarified risk profiles are also needed.

\section{Conflict of Interest}

The author have no conflict of interest.

\section{Disclosure}

The author did not received any type of commercial support either in forms of compensation or financial for this study. The author have no financial interest in any of the products or devices, or drugs mentioned in this article.

\section{Ethical Approval}

Obtained.

\section{References}

[1] Ragosta M, Dee S, Sarembock IJ, Lipson LC, Gimple LW, Powers ER. Prevalence of unfavorable angiographic characteristics for percutaneous intervention in patients with unprotected left main coronary artery disease. Catheter Cardiovasc Interv 2006; 68(3): 357-362.

[2] Taylor H, Deumite N, Chaitman B, Davis K, Killip J, Rogers $W$. Asymptomatic left main coronary artery disease in the Coronary Artery Surgery Study (CASS) registry. Circulation 1989; 79(6): 1171-1179.

[3] Caracciolo EA, Davis KB, Sopko G, Kaiser GC, Corley SD, Schaff H, Taylor HA, Chaitman BR. Comparison of surgical and medical group survival in patients with left main equivalent coronary artery disease: long-term CASS experience. Circulation 1995; 91 (9): 2335-2344.

[4] Fajadet J, Chieffo A. Current management of left main coronary artery disease. Eur Heart J 2012; 33(1): 36-50.

[5] Jönsson A, Hammar N, Nordquist T, Ivert T. Left main coronary artery stenosis no longer a risk factor for early and late death after coronary artery bypass surgery - an experience covering three decades. Eur J Cardiothoracic Surg 2006; 30(2): 311-317.

[6] Zalewska-Adamiec M, Bachórzewska-Gajewska H, Kralisz

P, Nowak K, Hirnle T, Dobrzycki S. [Prognosis in patients with left main coronary artery disease managed surgically, percutaneously or medically: a long-term follow-up] Kardiol Pol 2013; 71 (8): 787-795.

[7] Taggart DP, Kaul S, Boden WE, Ferguson TB Jr, Guyton RA, Mack MJ, Sergeant PT, Shemin RJ, Smith PK, Yusuf S. Revascularization for unprotected left main stem coronary artery stenosis stenting or surgery. J Am Coll Cardiol 2008: 51(9): 885-892. 


\section{عمليات توصيل الشرايين التاجية للقلب في حالات تضيق الجزع الشرياني الأيسر}

\section{حسين حمزة جباد}

قسم الجراحة، كلبة الطب، جامعة الدلك عبدالعزيز جلة - المدلكة العربية السعودية الطية العاية

المستخطص. إن تضيق الجذع الأيسر للشرايين التاجية مصحوب بخطورة عالية وإرتفاع فى نسبة الوفيات والإعتلال، تر اجع هذة الدراسة بيانات المرضى و نتائج التدخل الجراحى لهؤلاء المرضى فى جامعة الملك عبد العزيز بجدة.تتشمل هذه

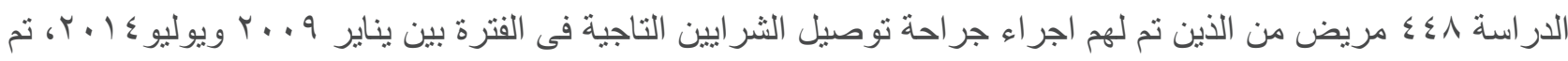

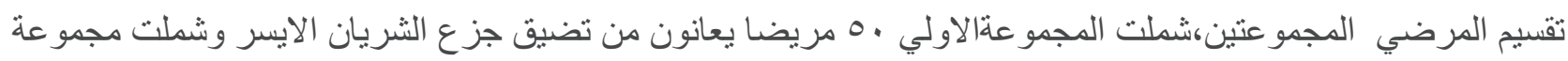

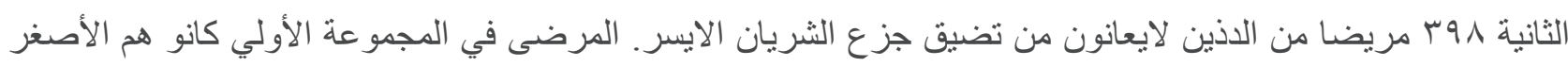

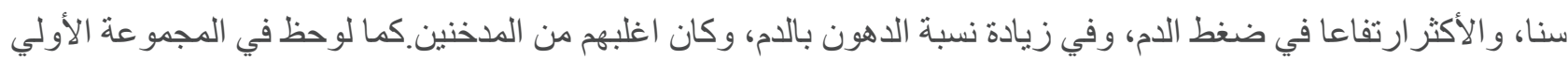
زيادة الإصابة بتضيق في الثر ايين التاجية الرئيسية الثلاثة، مع انخفاض كبيرفي وظائف القلب. لاحظنا ارتفاع نسبة الوفيات بعدلاحظنا ارتفاع نسبة الوفيات بعد الجراحة (^٪) في المجموعة الاولي بالمقارنة مع المجموعة الثانية (1 , ^٪)، وكان

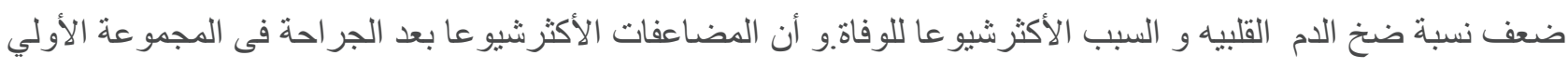

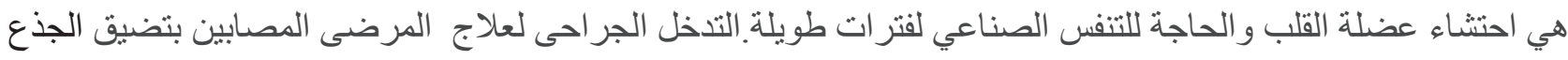
الأيسر للثر ايين التاجية مصحوب بخطورة عالية وإرتفاع فى نسبة الوفيات والإعتلال وذلك بسبب إرتفاع نسبة عوامل الخطورة لايهم و الحاجة للتنخل الجر احى العاجل إضافة إلى حالتهم الصحية الحرجة قبل العملية. 